\title{
Upaya Pembentukan Mekanisme Pertanggungjawaban Lingkungan Transnasional terhadap Polusi Kabut Asap di Asia Tenggara tahun 2015
}

\author{
Muhammad Iqbal Yunazwardi \\ Universitas Indonesia
}

\begin{abstract}
ABSTRAK
Tulisan ini membahas mengenai pentingnya gagasan komunikatif dalam menyelesaikan permasalahan kebakaran hutan dan lahan (karhutla) dan kabut asap lintas negara di Asia Tenggara, terutama pasca tahun 2015. Fenomena tersebut telah membuat banyak kerugian bagi aktor negara maupun non-negara. Oleh karena itu, gagasan komunikatif penting sebagai dasar pembangunan mekanisme pertanggungjawaban lingkungan transnasional. Gagasan komunikatif diciptakan dengan cara menentukan berbagai prinsip moral sebagai dasar pembentukan mekanisme pertanggungjawaban lingkungan yang ideal. Prinsip moral tersebut antara lain; (1) pencegahan bahaya, (2) inklusifitas, dan (3) keadilan prosedural. Dengan mengidentifikasi prinsip tersebut, aktor negara dan non-negara diharapkan mampu merepresentasikan ruang moral yang menginformasikan gagasan komunikatif pertanggungjawaban lingkungan transnasional. Tujuan normatif yang dihasilkan dari pertanggungjawaban lingkungan transnasional adalah kewajiban berbasis hak, mengikat norma-norma lingkungan dengan hak konstitusional atau hukum HAM.
\end{abstract}

Kata-kata Kunci: Pertanggungjawaban Lingkungan Transnasional, Prinsip Moral, Kabut Asap

This paper discusses the importance of "communicative notion" in solving the problem of forest and land fires (karhutla) and cross-country haze that occurred in Southeast Asia, especially after 2015. The adverse impact of haze that occurred in Southeast Asia has brought many losses for state and non-state actors. Therefore, the communicative notion is important as the basis for building an ideal mechanism for transnational environmental responsibility. The communicative notion is created by determining various moral principles as the basis for the establishment of an ideal environmental accountability mechanism. These moral principles include; (1) harm prevention, (2) inclusiveness, and (3) impartialty. $B y$ identifying these principles, state and non-state actors are expected to be able to represent the moral space agreed upon by communicative transnational environmental responsibility. Normative objectives resulting from transnational environmental responsibility are obinding environmental norms with constitutional rights or human rights law.

Keywords: Transnational Environmental Obligations, Moral Principles, Haze Pollution 
Ilmu Hubungan Internasional pada tahun 1970-an akhirnya mengangkat isu lingkungan hidup. Hal ini ditandai dengan penyelenggaraan Konferensi Perserikatan Bangsa-Bangsa tentang lingkungan hidup pada tahun 1972 di Stockholm, Swedia (Eckersley 2012 dalam Roby et al. 2012). Tindak lanjut dalam konferensi di atas kembali direalisasikan dalam konferensi PBB tentang lingkungan hidup di Rio, Brazil tahun 1992. Konferensi ini membuktikan bahwa masyarakat internasional semakin terdesak dalam melihat berbagai faktor lingkungan yang akan berdampak bagi masyarakat internasional (Eckersley 2010). Salah satu isu yang dibahas dalam pertemuan tersebut ialah permasalahan lingkungan selalu bersifat transnasional dan dibutuhkan mekanisme penanganan yang bersifat transnasional pula.

Isu ini dirasakan oleh masyarakat yang berada di Asia Tenggara. Pada bulan September hingga Oktober di tiap tahunnya, negara-negara di Asia Tenggara mulai dihadapi oleh permasalahan lingkungan, yaitu polusi asap akibat kebakaran hutan. Pada momen ini, industri kelapa sawit, kayu, hingga lahan gambut menjadi sumber utama titik api. Pembakaran lahan di atas adalah mekanisme tradisional yang digunakan oleh pengusaha industri tersebut untuk membersihkan lahan. Indonesia menjadi pelaku utama pembakaran hutan di mana titik api terbesar berasal dari dua pulau yang berada di teritori Indonesia, yaitu Sumatera dan Kalimantan.

Berbagai mekanisme kerja sama pun dilakukan untuk meminimalisir dampak dari polusi udara. Sejak tahun 1995, forum ASEAN berusaha membawa isu polusi udara menjadi isu penting yang harus dibicarakan oleh negara anggota ASEAN. Kebakaran polusi asap besar pada tahun 1997 hingga 1998 akhirnya mendorong ASEAN untuk mengintensifkan upaya kerja sama untuk menanggulangi ancaman polusi asap yang semakin serius. Mekanisme tersebut semakin nyata saat negara anggota ASEAN mulai meratifikasi perumusan ASEAN Agreement on Transboundary Haze Pollution (AATHP) pada tahun 2002. Walau telah diratifikasi oleh ke-10 negara anggota ASEAN pada tahun, kesepakatan ini terlihat tidak efektif dalam mengatasi bencana karhutla dan kabut asap yang dihadapi kawasan Asia Tenggara.

World Bank dalam rilis resminya menyatakan bahwa polusi kabut asap di Asia Tenggara adalah tindakan kriminal lingkungan hidup terbesar pada abad ke-21. Kerusakan lahan yang tak terkendali berdampak bagi kesehatan, pendidikan, dan penghidupan jutaan masyarakat. Total kerugian yang dihadapi oleh negara-negara terdampak mencapai \$16 miliar dolar (World Bank 2015). Selain 
itu, korban yang paling jarang disorot dalam konteks pertanggungjawaban lintas negara atas polusi kabut asap adalah masyarakat yang secara langsung terdampak. Selain itu, karhutla di ASEAN berdampak pada 28 juta penduduk, 19 orang meninggal, dan hampir lima ratus ribu orang mengalami gangguan pernapasan atau ISPA.

Dalam melihat sebab terjadinya kebakaran hutan, aktor nonnegara seperti organisasi non-pemerintah (NGO) menuntut adanya transparansi pertangungjawaban lintas negara yang tidak hanya menciptakan kerja sama regional, tetapi mampu bertindak tegas untuk menindak korporasi-korporasi yang bertanggung jawab atas kebakaran hutan dan lahan. Semakin berkembangnya ancaman lingkungan transnasional membutuhkan hadirnya pertanggung jawaban demokratis yang melibatkan aktor negara maupun non negara. Salah satu aspek terpenting dalam membangun sebuah mekanisme tersebut, penulis melihat pentingnya membangun sebuah ruang diskursif yang mampu membawa gagasan komunikatif mengenai pembenaran kerugian yang dihadapi oleh aktor publik maupun swasta, terutama terkait permasalahan kabut asap lintas negara yang terjadi di Asia Tenggara pada tahun 2015.

\section{Kajian Konseptual: \\ Pertanggungjawaban Lingkungan Transnasional}

Dalam hukum internasional, hak kedaulatan negara untuk mengeksploitasi sumber dayanya sendiri dibatasi oleh prinsip inti tanggung jawab lingkungan, yaitu memastikan bahwa kegiatan dalam yuridiksi atau kontrol teritorial mereka tidak menyebabkan kerusakan lingkungan ke negara lain. Norma ini pertama kali ditetapkan secara deklaratif sebagai prinsip 21 dari Deklarasi Stockholm tentang Lingkungan Manusia (1972) dan disajikan kembali pada Konferensi PBB tentang Lingkungan dan Pembangunan (UNCED) pada Prinsip No.2 Deklarasi Rio tentang lingkungan dan pembangunan (Mason, 2001). Dalam perkembangan untuk membangun pertanggungjawaban lintas negara, dimungkinkan untuk mengajak keterlibatan aktor non-negara seperti NGO. Peran NGO dianggap mampu mewakili publik yang terkena dampak lingkungan transnasional (Diller 2001).

Kerugian transnasional pada akhirnya memberikan alasan kuat untuk memperkuat batas komunitas moral dan politik yang melibatkan pihak lain dalam dialog-dialog yang mempengaruhi kepentingan penting mereka (Thomas dan Steans 2005). Dalam hal ini, gagasan komunikatif berfungsi untuk mengadopsi hubungan non koersif, timbal balik dan menerima kewajiban apapun yang 
berasal dari ucapan dan tindakan yang disepakati bersama. Gagasan komunikatif dalam pertanggungjawaban lingkungan berusaha membangun sebuah kewajiban moral yang mengajak semuah pihak yang berdampak untuk membangun sebuah komunikasi yang utuh dan secara rasional mampu mempertimbangkan konsekuensinya. Melalui narasi di atas, Mason melihat perlunya tiga prinsip moral yang diperlukan untuk pewacanaan publik yang terdampak, yaitu pencegahan bahaya, inklusifitas, dan impartiality (Mason 2001)

Pencegahan bahaya adalah moral prioritas dalam hukum lingkungan internasional yang memberikan kewajiban umum untuk tidak menyebabkan kerusakan lingkungan dan mencerminkan penerimaan dari no-harm principle dalam pemerintahan global. Berbagai kewajiban negara untuk tindakan internal dan eksternal berasal dari prinsip ini, tetapi yang paling penting bagi kerusakan lingkungan lintas batas negara adalah kewajiban untuk melakukan tindakan terhadap negara yang membutuhkan pencegahan kerusakan terhadap lingkungan. Selanjutnya, Inclusiviness adalah representasi kepentingan publik yang terkena dampak transnasional membutuhkan pengakuat formal atas hak partisipasi untuk NGO dalam tata kelola lingkungan global. Variabel ini mendorong perluasan hak partisipasi NGO, yaitu dengan memberikan akses terhadap perumusan dan implementasi hukum hingga penetapan standar lingkungan internasional. Terakhir, impartiality adalah prinsip moral untuk menjelaskan keterlibatan NGO dalam tata kelola global diyakini akan diimbangi oleh keterlibatan kelompok kepentingan seperti korporasi dalam negosiasi norma dan aturan lingkungan. Perluasan ruang diskusi dari pengembangan norma dan legitimasi untuk memasukkan representasi non negara bergerak ke arah prinsip inklusi yang ditunjukkan oleh formulasi komunikatif dari pertanggungjawaban transnasional. Impartiality digunakan untuk menghadirkan keadilan prosedural dalam pengembangan norma, khususnya untuk mengakui klaim dari negara-negara miskin maupun pihak-pihak yang termarjinalkan.

Konvergensi dari prinsip di atas dianggap mampu merepresentasikan ruang moral yang menginformasikan gagasan komunikatif pertanggungjawaban lingkungan transnasional. Tujuan normatif yang dihasilkan dari pertanggungjawaban lingkungan transnasional adalah kewajiban berbasis hak, mengikat norma-norma lingkungan dengan hak konstitusional atau hukum HAM berbasis negara. Gagasan komunikatif memiliki kemampuan untuk merefleksikan bahasa yang digunakan untuk mengekspresikan kebenaran proposisional, nilai normatif, atau ekspresi diri subjektif. Menurut Linklater (2006), upaya untuk menciptakan kerangka kerja sama 
untuk menangani kerusakan lingkungan global tidak mungkin berhasil tanpa perubahan besar dalam kehidupan emosional komunitas politik yang telah terpisah. Gagasan ini merupakan bagian dari etika kosmpolitan. Dimana dalam isu lingkungan, manusia jarang memberikan perhatian terhadap prinsip-prinsip moral yang terpisah, dalam keyakinannya untuk bertanggung jawab atas penderitaan orang lain.

\section{Prinsip Moral dalam Pencegahan Bahaya atas Polusi Kabut Asap}

Masalah lingkungan di Asia Tenggara menjadi isu penting sejak terjadinya tragedi kabut asap pada tahun 1997. Kebakaran hutan dan lahan yang terjadi di Indonesia telah merugikan negara tetangga seperti Malaysia, Singapura, dan Brunei Darussalam. Kabut asap telah menjadi masalah serius dimana, hukum internasional telah menetapkan bahwa suatu negara dilarang untuk melakukan tindakan yang merugikan negara lain(UNCHE 1972 Point 21). Selain itu, kabut asap juga menyinggung HAM dimana hak atas lingkungan hidup dilanggar. Akibat kabut asap, lebih dari 75 juta penduduk di negara-negara yang terdampak terpapar oleh berbagai zat pembakaran seperti Sulfur dioksida, karbon monooksida, benzen, nitrogen oksida, dan ozon (Tuk Indonesia 2016).

Dalam melihat kebutuhan atas pengelolaan dan pencegahan kabut asap di kawasan, ASEAN akhirnya berhasil membuat kerangka kerja sama pengelolaan isu kabut asap di Asia Tenggara melalui ASEAN Agreement on Transboundary Haze Pollution (AATHP) (AATHP 2014). Dalam draft resminya, AATHP berinisiatif untuk melakukan tindakan individu dan bersama untuk menganalisis asap, penyebab tingkat kebakaran lahan dan kabut asap yang dihasilkan. Hal tersebut dilakukan dengan cara mencegah dan mengendalikan sumber-sumber kebakaran hutan dan kabut yang dihasilkan. Pencegahan dilakukan dengan cara menerapkan kebijakan, praktik dan teknologi lingkungan yang sehat untuk memperkuat kapabilitas nasional. Pencegahan bahaya sedari awal tercantum dari isi AATHP. Misal dalam pasal 4 poin 1, negara anggota ASEAN diharapkan untuk bekerja sama untuk mengembangkan dan mengimplementasikan pencegahan dan pelacakan polusi kabut asap transnasional. Akan tetapi, mekanisme kerja sama hanya dianggap efektif apabila negara yang menjadi penyebab kebakaran hutan meminta bantuan atau konsultasi. Hal ini tertaut dalam poin 2 di pasal yang sama.

Poin dalam AATHP yang juga sangat bergantung pada prinsip ASEAN Way juga dapat dilihat pada pasal 5. Dimana pusat 
pengendalian kabut asap ASEAN akan bekerja berdasarkan otoritas nasional. Otoritas nasional akan berinisiatif untuk meminta bantuan apabila telah menyatakan situasi darurat. Akan tetapi, sulit bagi kita untuk melacak bagaimana sebuah negara mampu untuk memberikan status darurat negara terhadap polusi kabut asap, (Varkkey 2016). Negara pada dasarnya selalu merasa bahwa kapabilitas yang dimiliki mampu mencegah dan memadamkan kebakaran hutan. Pada akhirnya upaya tersebut tidak bisa dikatakan maksimal sepenuhnya. Pada tahun 2014 dan 2015, Indonesia terus berjibaku dengan tuntutan masyarakat Indonesia hingga negara tetangga atas lambatnya penyelesaian kabut asap. Inisiatif Indonesia untuk meminta bantuan kepada ASEAN juga tidak dilakukan. Padahal, ASEAN melalui AATHP memiliki mekanisme kerja sama yang dianggap mampu membantu Indonesia dibanding hanya memanfaatkan dengan kapabilitas domestik untuk menyelesaikan kabut asap.

Dalam sebuah kutipan yang diberikan oleh George Lantu, Direktur Kerja Sama Fungsional ASEAN Kementerian Luar Negeri, pemerintah Indonesia memiliki alasan untuk tidak menjadikan AATHP sebagai landasan. Alasan utama yaitu AATHP memiliki kerumitan mekanisme (CNN Indonesia 2015). Dalam pasal 12 AATHP, jika suatu negara ingin meminta bantuan dalam menangani permasåalahan karhutla dan kabut asap, maka harus melalui permohonan dan persetujuan bersama. Mekanisme konsensus ini adalah bagian penting dan pemerintah melihat fungsi ini lebih rumit dibandingkan meminta pertolongan secara bilateral.

Walaupun begitu upaya untuk menggunakan cara bilateral tidak juga dimaksimalkan oleh Indonesia. Walaupun negara-negara seperti Malaysia dan Singapura telah memberikan penawaran bantuan untuk memadamkan titi api dan membuat rekayasa hujan, Indonesia tetap berkilah bahwa kapabilitas yang dimiliki dianggap sanggup untuk memadamkan api. Seperti contoh pada September 2015, Menteri Pertahanan Singapura saat itu, Ng Eng Hen menyatakan bahwa tentara Singapura gagal untuk berangkat memadamkan api di Sumatera setelah Menteri Lingkungan Hidup Indonesia, Siti Nurbaya menolak bantuan tersebut dengan menyatakan bahwa Indonesia masih mampu untuk mengerahkan 20 pesawatnya untuk menciptakan hujan buatan dan melakukan pengeboman air (Mongabay 2015). Walaupun pada akhirnya, Indonesia membuka pintu bagi negara-negara di atas untuk membantu. Dalam melihat kepentingan Indonesia terhadap perilaku di atas, pernyataan dari Juru Bicara KLHK, Jati Witjaksono dapat disimpulkan sebagai alasan yang cukup rasional. Menurutnya, alasan mengapa Indonesia 
menolak bantuan dari negara lain diakibatkan posisi negara untuk menjaga martabat bangsa (Okezone 2019) Permintaan atau penerimaan bantuan dari negara lain sarat dengan asumsi yang melecehkan. Hal tersebut dikarena Indonesia dianggap tidak mampu untuk menyelesaikan permasalahan domestiknya.

Varrkey (2016) melihat bahwa keenganan negara-negara Asean untuk melaksanakan visi kesepakatan kawasan dapat dikaitkan erat dengan eksistensi norma ASEAN Way. ASEAN Way adalah seperangkat norma prosedural yang mengutamakan konsensus, kesakralan hak kedaulatan \& non intervensi, prinsip sensivitas, pendekatan non-konfrontatif untuk negosiasi, diskusi di belakang layar, hingga penekanan pada prosedur informal dan non-legalistik; dan fleksibilitas. Gambaran yang ditimbulkan dari penerapan prinsip ASEAN Way dinilai menjadi hambatan penting bagi pengelolaan kabut asap di Asia Tenggara. Dampak dari penerapan ASEAN Way pada akhirnya menyulitkan isu-isu lingkungan transnasional digunakan sebagai mekanisme ideal dalam menyelesaikan polusi kabut asap transnasional dan lebih mengandalkan hukum domestik.

Pertanggungjawaban lintas negara dianggap mampu tercipta apabila tiap aktor mampu mengimplementasikan prinsip moral pencegahan bahaya dalam kerangka kerja sama yang lebih luas. Menurut Mason (2001), kesepakatan yang dibangun diharap mampu membangun kewajiban untuk melakukan tindakan terhadap negara yang memerlukan pencegahan kerusakan pada lingkungan. Upaya menciptakan kesepakatan yang tidak lagi terhalang prinsip non-intervensi menjadi urgensi utama. Di mana, tidak ada lagi jurang pemisan antar negara dalam menyelesaikan permasalahan lingkungan yang berdampak regional.

\section{Inklusifitas dalam Pertanggungjawaban Kabut Asap Transnasional}

Isu lingkungan telah membutuhkan peran organisasi sektor swasta. Dalam hal ini, NGO menjadi agen kritis non pemerintah yang menuntut pengakuan dan tindakan isu, menjadi mitra dalam mengembangkan kerangka kerja dan membangun prinsip yang diaplikasikan melalui aksi kampanye lingkungan (Gough dan Shackley 2001). Isu lingkungan juga mengantarkan era baru keterlibatan pemberdayaan NGO dengan memberi mereka tempat di meja perundingan. Legitimasi NGO sebagai aktor lingkungan muncul dari klaim mereka yang mewakili opini publik yang cukup besar dan tidak cukup terwakili dalam proses perumusan kebijakan. Tindakan efektif yang dilakukan oleh NGO di skala 
nasional biasanya melibatkan mobilisasi opini publik melalui media dan memberikan tekanan secara langsung dan tidak langsung pada jaringan kebijakan dan jaringan koalisi NGO lainnya. Dalam tulisannya, Mason menganggap terciptanya inklusifitas ditandai dengan partisipasi peran NGO sebagai perwakilan non negara bagi korban yang terdampak.

Dalam peristiwa kabut asap lintas negara Asia Tenggara pada tahun 2015, NGO internasional yang berdomisili di negara-negara Asia Tenggara maupun NGO nasional memainkan peran untuk mengkritik peran negara dalam menyelesaikan permasalahan kabut asap. Sebagai sebuah gerakan sosial, NGO bergerak atas dasar keluhan kolektif dari masyarakat yang tertindas akibat dampak dari karhutla dan polusi kabut asap. Keluhan tersebut menjadi dasar terbukanya struktur politik yang mampu membangun mobilisasi dalam lingkup peran advokasi kebijakan, kampanye publik, pengembangan kapasitas, konsultasi pengelolaan dan manajemen kebakaran hutan hingga aksi dilapangan (Rautsiala 1997). Struktur mobilisasi dibangun melalui kerja sama antar NGO lingkungan yang memiliki misi untuk menyelesaikan permasalahan kabut asap. Dalam isu kabut asap 2015, peran NGO yang paling terlihat adalah advokasi kebijakan. Di Indonesia, beberapa NGO yang aktif untuk menyarakan kepentingan korban terdampak atas karhutla dank abut asap antara lain WALHI, Greenpeace, dan Sawit Watch. NGO tersebut membangun perlawanan politik untuk membawa suara-suara yang termarjinalkan seperti masyarakat adat maupun masyarakat yang terdampak langsung oleh kabut asap. Perlawanan tersebut di arahkan kepada penguasa, pemegang otoritas, dan terutama kepada perusahaan yang dianggap bertanggung jawab terkait dengan terjadinya karhutla dan kabut asap.

Aktivitas kelompok masyarakat sipil juga memiliki pengaruh untuk memberikan pertolongan kepada masyarakat yang terdampak langsung oleh kabut asap. Di Indonesia, berbagai aktris seperti Alyra Rohali, Zaskia Sungkar dan Yuni Shara melakukan inisiasi "Gerakan Sejuta Tangki Oksigen”, sebuah proyek kolaborasi dengan yayasan nirlaba Rumah Pandai Indonesia (Chen dan Yi 2015). Selain itu, organisasi kemanusiaan Palang Merah Indonesia juga melakukan operasi tanggap darurat di wilayah Sumatera dan Kalimantan untuk mendistribusikan tangki oksigen, masker wajah, obat tetes mata, dan pasokan susu untuk anak. Organisasi relawan internasional seperti Palang Merah Internasional dan Bulan Sabit Merah, Palang Merah AS dan Palang Merah Australia juga turun langsung untuk membantu perawatan medis kepada kelompok rentan. 
Selain bantuan kemanusiaan, NGO juga memanfaatkan kedekatan mereka dengan target pembakaran dan jaringan yang luas untuk menyediakan sistem pemeriksaan atas kebakaran hutan yang terjadi. Upaya yang dilakukan bertujuan untuk mencegah agen pemerintah dan perusahaan besar menyalahgunakan kekuasaan dan pengaruhnya, atau mengabaikan tanggung jawab. Organisasi tersebut antara lain koalisi NGO bernama Eyes on the Forest (EoF). EoF adalah jaringan koalisi yang terdiri dari Jikalahari (Jaringan Penyelamatan Hutan Riau), WALHI (Wahana Lingkungan Hidup Indonesia) dan WWF (World Wide Fund For Nature).

Pemantauan dilakukan dengan menciptakan sistem pemantauan titik api dan gambar satelit sebagai data yang bersifat independen. Temuan penting dari data tersebut yaitu kebakaran berasal dari empat konsesi yang memasok kebutuhan industri dari perusahaan kertas terbesar di Indonesia, Asia Pulp dan Paper (APP) (Chen dan Yi 2015). Selain di Indonesia, beberapa NGO Muslim Malaysia menyatakan niat mereka untuk mengajukan gugatan terhadap perusahaan yang bertanggung jawab atas kebakaran di Indonesia. Total organisasi yang terlibat yaitu 250 NGO dengan mewakili satu juta masyarakat Malaysia. Koalisi NGO Muslim Malaysia menyatakan bahwa masyarakat merasa telah terlibat aktif dalam gerakan masyarakat sipil untuk mengatasi dan memberi solusi terhadap penyelesaian kabut asap. Masyarakat Malaysia telah bergerak secara nyata dan mengurangi ketergantungan kepada pemerintah untuk mengatasi krisis dan ketidak adilan dalam penanganan kabut asap.

Tetapi, prinsip inklusifitas dapat tercipta apabila peran aktor nonnegara tidak hanya sekedar sebagai political pressure atau contentious politics. NGO diharapkan memiliki akses untuk berkontribusi dalam penerapan dan pembuatan kerangka kerja sama hingga hukum lingkungan internasional. Dalam penerapan AATHP sebagai mekanisme kerja sama penerapan pertanggungjawaban kabut asap di Asia Tenggara, peneliti tidak melihat peran yang signifikan dari aktor-aktor non negara dalam perumusan kesepakatan tersebut. Dalam sejarah pendirian AATHP hingga berbagai pertemuan, upaya kerja sama untuk mengatasi ancaman lingkungan di Asia Tenggara hanya dilakukan oleh negara-negara yang tergabung dalam anggota ASEAN. Tidak terlihat bagaimana partisipasi dari aktor-aktor non negara seperti NGO dalam perumusan kebijakan yang mampu membawa suara-suara yang tidak terwakili dalan isu kabut asap. Pada prosedur operasionalisasi standar untuk pemantauan, penilaian dan tanggap darurat bersama, aktor non negara hanya dimanfaatkan sebagai sumber informasi dalam mengembangkan rekomendasi pengendalian polusi asap 


\section{Keadilan Prosedural dalam Pengembangan Prinsip Moral Pertanggungjawaban Kabut Asap Transnasional di Asia Tenggara}

Untukmembangun sebuahkerangkakerjasamapertanggungjawaban transnasional, dibutuhkan perimbangan keterlibatan dari kepentingan sektoral. Perimbangan ini bertujuan untuk memperluas ruang interlokus pembangunan norma untuk memasukkan aktor non negara yang mewakili kepentingan publik terdampak. Norma yang dibangun haruslah mampu adil dan dapat diterima oleh aktor negara maupun non negara. Seperti contoh, negosiasi lingkungan internasional harus mempertimbangkan keadilan prosedural dan distributif dalam pembangunan norma (Mason 2001).

Dalam kasus kabut asap di Asia Tenggara, pihak yang dianggap paling terdampak adalah masyarakat (Yulianti 2018). Masyarakat sebagai pihak yang paling terdampak adalah potret dari dampak praktik pembakaran hutan di Indonesia. Selain itu, terdapat kerugian yang berimplikasi pada pemenuhan dan perlindungan hakhak asasi manusia seperti hak atas hidup, hak untuk mendapatkan tempat tinggal yang layak, akses air yang layak, hak atas pendidikan, ekonomi mapun perlindungan masyarakat hukum adat yang masih menetap di wilayah-wilayah yang terdampak pada rusaknya tempat tinggalnya.

Koalisi NGO telah mewakili suara mereka yang terdampak dengan cara menekan perusahaan konsensi yang terbukti melakukan pembakaran hutan. Hasil penelitian dari The Centerfor Internasional Forestry Research (CIFOR) menunjukkan, perusahaan-perusahaan memiliki motif untuk membakar lahan dikarenakan biaya dikeluarkan sangatlah sedikit, yaitu hanya mengeluarkan biaya sekitar Rp 600 ribu per hektare, lebih mahal dibandingkan melalui mekanisme tidak membakar yaitu Rp 3,4 juta hectare (KONTRAS 2015) Keberpihakan terhadap masyarakat sendiri dapat dilakukan dengan cara membangun sebuah kerangka kerja sama yang mampu mendorong pertanggungjawaban kelompok-kelompok bisnis dan korporasi. Mekanisme kerja sama lintas negara diharapkan mampu mendorong negara untuk bertanggung jawab melindungi masyarakatnya dencan cara mengambil langkah tepat untuk menyelediki, menghukum, dan menyediakan mekanisme ganti rugi atas kejahatan bisnis yang terjadi.

Indonesia dianggap bertanggung jawab atas kagagalan dalam mengatur dan menegakkan aturan tentang perkebunan kelapa sawit, kayu pulp hingga lahan gambut. Dilematisnya, peraturan 
pembakaran ini ternyata tidak sepenuhnya dilarang oleh Indonesia. Sebagai contoh, Pasal 69 ayat 1 UU Perlindungan Lingkungan Hidup Indonesia dan Pasal 4 Peraturan Menteri Lingkungan Hidup Indonesia tahun 2010 memungkinkan para petani setempat untuk membersihkan lahan dengan api dengan maksimum pembakaran yaitu dua hektar (Listriningrum 2017) Walau dirugikan akibat aturan tersebut, Malaysia dan Singapura tidak memiliki opsi yang cukup untuk menekan Indonesia. Opsi tersebut sulit tercipta dikarenakan beberapa perusahaan yang melanggar aturan pembakaran lahan berasal dari dua negara tersebut. Bahkan pembakaran lahan juga dilakukan di Sarawak (Malaysia).

Jaringan Koalisi NGO Indonesia Eyes On The Forest mencatat bahwa pembakaran hutan dan lahan yang terjadi pada tahun 2015 adalah kejahatan kemanusiaan. Korporasi kebun akasia (HTI) dan kebut sawit dianggap bertanggung jawab mempraktekan pembakaran dengan motif ekonomi. Total 12 perusahaan yang terafiliasi dengan Asia Pacific Resources International Limited (APRIL) dan empat perusahaan yang terafilisasi dengan APP dianggap bertanggung jawab untuk membersihkan lahan konsesi dengan metode pembakaran (Eyes On The Forest 2015). Walau pemerintah Indonesia bertindak tegas dengan menghukum dan memberikan denda kepada perusahaan yang terbukti secara sah melakukan pembakaran, biaya denda belum bisa untuk didapatkan pemerintah. Pemerintah Indonesia telah mengklaim memenangkan kasus senilai 7,8 trilyun Rupiah sejak 2014, seputar dugaan pembakaran atas 20.000 hektar lahan yang dikuasai Bumi Mekar Hijau, perusahaan kayu yang menginduk pada Sinarmas/APP. Meski uang denda sudah dikurangi menjadi 78 milyar Rupiah pada 2016 lalu, hingga kini perusahaan tersebut belum melunasi denda (DW 2015)

Selanjutnya pengalaman di Singapura, Dewan Lingkungan Singapura (SEC) telah menggunakan pengaruh dan sumber daya yang dimiliki untuk menerapkan langkah-langkah hukuman. Sebagai sebuah NGO yang memiliki pengaruh yang cukup besar, SEC mampu untuk menangguhkan produk APP yang menggunakan label hijau. Akibat tekanan dari SEC, berbagai supermarket besar di Singapura seperti NTUC Fairprice, Sheng Siong, dan Prime Supermarket telah menarik semua produk APP dari gudang dan toko mereka. Selain itu, koalisi jaringan NGO Singapura yang terdiri dari WWF Singapura, PM.Haze dan Singapore Institute of International Affairs (SIIA) juga meluncurkan kampanye kabut asap bertajuk "We Breathe What We Buy". Kampanye ini bertujuan untuk mengedukasi warga Singapura tentang praktik berkelanjutan atas produksi minyak sawit dan dampaknya terhadap kerusakan hutan dan kabut asap. Jaringan 
koalisi ini berusaha untuk mendorong perusahaan sawit agar mampu mengikuti standar produksi yang pro lingkungan dan mendorong adopsi penggunaan sertifikasi minyak sawit berkelanjutan (CSPO) (Chen \& Yi 2015). Upaya ini dilakukan sebagai bentuk keadilan prosedural di mana negara diharapkan mampu mewadahi suara masyarakat yang rentan dan terdampak atas kasus kabut asap yang menimpa Singapura.

Pada akhirnya, mekanisme keadilan prosedural diharapkan mampu diusahakan tidak hanya pada tataran domestik, tetapi juga mampu mempengaruhiperumusankebijakan dalamtatanan regional.AATHP sebagai mekanisme yang eksis dianggap memiliki mekanisme yang lemah dalam memulihkan keadaan dan memberikan akses terhadap keadilan. Oleh karena itu, keadilan prosedural tidak hanya dilakukan untuk meminta pertanggungjawaban Indonesia, tetapi juga mampu untuk meminta pertanggungjawaban kepada pelaku swasta yang terlibat dalam kebakaran hutan dan lahan di Indonesia. Keadilan prosedural sulit terjadi saat manajemen kerangka kerja sama lintas negara tidak mampu untuk bertindak tegas dalam mewakili aspirasi masyarakat yang terdampak. Salah satu aspirasi terbesar adalah tindakan tegas dari negara-negara untuk menghukum perusahaan yang secara terbukti terlibat melakukan pembakaran hutan dan lahan.

\section{Kesimpulan}

Kabut asap lintas negara pada tahun 2015 telah menjadi pekerjaan rumah yang sangat besar bagi ASEAN maupun negara-negara yang berada di Asia Tenggara. Ancaman kabut asap tiap tahunnya diprediksi akan terus terjadi apabila ASEAN dan negaranegara anggota tetap tidak mampu untuk membantu kerangka pertanggungjawaban transnasional yang ideal dalam menangani kabut asap lintas di Asia Tenggara tiap tahunnya. Berbagai mekanisme kerja sama penanggulangan kabut asap sebenarnya sudah dilakukan. Salah satu kesepakatan yang berhasil dicapai yaitu AATHP dan telah diratifikasi oleh selurung negara anggota ASEAN.

Tetapi untuk membangun sebuah pertanggungjawaban lintas batas negara, dibutuhkan gagasan komunikatif untuk menciptakan mekanisme pertanggungjawaban lingkungan transnasional yang ideal. Karena pada dasarnya, pertanggungjawaban lingkungan transnasional membutuhkan ruang moral wacana publik. Dibutuhkan sebuah norma yang membangun komitmen secara moral dan menempatkan kepentingan pihak yang terdampak dalam sebuah wadah bersama. Krisis lingkungan transnasional memberikan 
alasan kuat untuk memperluas batas komunitas moral dan politik untuk melibatkan pihak lain dalam dialog yang mempengaruhi kepentingan vital mereka. Pada prinsip moral pencegahan bahaya, mekanisme kerangka kerja yang dibangun ASEAN selalu terbentur dengan prinsip non intervensi yang dibangun pada ASEAN Way. Prinsip non intervensi mempersulit pengelolaan lingkungan di Asia Tenggara karena dampak yang dihasilkan dari kabut asap membutuhkan mekanisme yang mampu melewati batas negara. Sedangkan pada prinsip impartiality, peran aktor non negara seperti NGO masih belum terlalu maksimal untuk mengakomodir kepentingan politiknya di ranah perumusan kebijakan. Hingga saat ini, peran NGO hanya berupaya untuk mengadvokasi, kampanye, pengawalan hukum masyarakat yang terdampak. Selain itu, NGO berposisi menggunakan politik kritis untuk menyerang negara dan perusahaan yang terbukti bertanggung jawab memicu titik api dan polusi kabut asap. Sedangkan pada prinsip moral impartiality, hingga saat ini keberpihakan terhadap masyarakat yang terkena dampak kabut asap belum terwakili oleh kesepakatan regional yang telah dibuat. 


\section{Daftar Pustaka}

\section{Buku atau Bagian dalam Buku}

Dobson, Andrew dan Robyn Eckersey, 2006. Political Theory and the Ecological Challange. New York: Cambridge University Press

Fischer, Frank, 2015. "Environmental Democracy" dalam Karin Bäckstrand dan Eva Lövbrand (eds.), Research Handbook on Climate Governance. London: Edward Elgar Publishing.

Richard Devetak et al., 2012. An Introduction to International Relations. New York: Cambridge University Press

Eckersley, Robyn, 2010. "Green Theory" dalam Tim Dunne et al. (eds.), International Relations Theory. Oxford: Oxford University Press.

Fremaux, Anne dan John Barry, 2019. "The 'Good Anthropocene' and Green Political Theory: Rethinking Environmentalism, Resisting Ecomodernism" dalam Frank Biermann (ed.), Anthropocene Encounters: New Directions in Green Political Thinking. New York: Cambridge University Press

Heywood, Andrew, 2011. Global Politics. London: Palgrave Macmillan

Paterson, Matthew, 2005. "Green Politics", dalam Scott Burchill (ed.), an Introduction of International Relations. New York: Palgrave Macmillan.

Yulianti, Nina, 2018. Pengenalan Bencana Kebakaran dan Kabut Asap Lintas Batas. Bogor: IPB Press

\section{Artikel Jurnal}

Clark, Ann Marie et al., 1998. "The Sovereign Limits of Global Civil Society: A Comparison of NGO Participation in UN World Conferences on the Environment, Human Rights, and Women", World Politics, 51 (1): 1-35

Diez, Thomas, dan Jill Steans, 2005. "A Useful Dialogue? Habermas and International Relations", Review of International Studies, 31 (1): $127-40$. 
Diller, Janelle, 2001. "On the Possibilities and Limitations of NGO Participation in International Law and Its Processes: Corporate Applications" Proceedings of the Annual Meeting (American Society of International Law), 95: 304-309

Falkner, Robert, dan Robert Falkner 2019. "Global Environmentalism and the Greening of International Society", International Affairs, 88 (3): 503-522.

Hey, Ellen, 2013. "International Institutions and Global Environmental Governance", Proceedings of the Annual Meeting-American Society of International Law, 100.

Listiningrum, Prischa, 2018. "Transboundary Civil Litigation for Victims of Southeast Asian Haze Pollution: Access to Justice and the Non-Discrimination Principle", Transnational Environmental Law, 8 (1): 119-142.

Mason, Andrew, 2009. "Environmental Obligations and the Limits of Transnational Citizenship", Political Studies, 57 (2): 280297.

Mason, Michael, 2001. "Transnational Environmental Obligations: Locating New Spaces of Accountability in a Post-Westphalian Global Order", Transactions of the Institute of British Geographers, 26 (4): 407-429.

Mason, Michael, 2008. "The Governance of Transnational Environmental Harm: Addressing New Modes of Accountability/Responsibility", Global Environmental Politics, 8 (3): 8-24.

Ng, Kexian, 2017. "Transboundary Haze Pollution in Southeast Asia: The Effectiveness of Three Forms of International Legal Solutions", Journal of East Asia and International Law, 10 (1): 221-244.

Nurmadiansyah, Eko, 2015. "Konsep Hijau: Penerapan Green Constitution dan Green Legislation dalam Rangka EcoDemocracy", Veritas et Justitia, 1 (1): 183-219.

Paterson, Matthew, 1999. "Interpreting Trends in Global Environmental Governance.” International Affairs, 75 (4): 793-802. 
Payne, Rodger A. 1996. "Deliberating Global Environmental Politics”, Journal of Peace Research, 33 (2): 129-136.

Radavoi, Ciprian, dan Yongmin Bian, 2014. "Enhancing the Accountability of Transnational Corporations: The Case for 'Decoupling' Environmental Issues", Environmental Law Review, 16 (3): 168-182.

Raustiala, Kal, 1997. "States, NGOs, and International Environmental Institutions”, International Studies Quarterly, 41 (4): 719740 .

Rum, Muhammad, 2016. “The Case of Regional Disaster Management Cooperation in ASEAN: A Constructivist Approach to Understanding How International Norms Travel", Southeast Asian Studies, 5 (3): 491-514

Saragih, Yulie Monaliza, 2017. "Prinsip Pertanggungjawaban Negara terhadap Pencemaran Udara Lintas Batas Akibat Kebakaran Hutan Indonesia menurut Asean Agreement on Transboundary Haze Pollution", Jurnal Pandecta, 12 (1): 5166.

Varkkey, Helena, 2012. "The Asean Way and Haze Mitigation Efforts", Journal of International Studies, 8: 77-97.

\section{Instrumen Legal}

ASEAN, 2016. Asean Agreement on Transboundary Haze Pollution. Jakarta: The ASEAN Secretariat

PBB, 1972. Declaration of the United Nations Conference on the Human Environment. New York: Secretariat of the United Nations.

\section{Laporan Penelitian}

Dann, Christine, 1999. “From Earth’s Last Island: The Global Origins of Green Politics", Tesis Doktoral. Lincoln: Department of Envrionmental Management Lincoln University.

Eyes on The Forest, 2015. "Terlibat kejahatan kemanusiaan, para pelaku layak diseret ke pengadilan: Pengecekan lapangan di 37 lokasi terdeteksi titik api 2015”, Laporan Investigasi Oktober -November 2015. Pekanbaru: Eyes on the Forest. 
KONTRAS, 2015. "Asap dan Residu Hak Asasi: Jauhnya Pertanggungjawaban Negara Untuk Menghukum Perusahaan Pembakar Hutan dan Melindungi Hak-Hak Dasar Warga Indonesia”, Laporan. Jakarta: KONTRAS.

Tay, Simon et al., 2016. "Southeast Asia's Burning Issue: From The 2015 Haze Crisis to A More Robust System”, Policy Brief, April. Singapura: Singapore Institute of International Affairs.

\section{Publikasi Daring}

ASEAN, 2015. "COP to AATHP (Conference of the Parties to the ASEAN Agreement on Transboundary Haze Pollution)" [daring]. Tersedia dalam https://asean.org/asean-sociocultural/cop-to-aathp-conference-of-the-parties-to-theasean-agreement-on-transboundary-haze-pollution/ [Diakses 1 Oktober 2019].

ASEAN, 2015. "ASEAN Ministerial Meeting on Environment (AMME)" [daring]. Tersedia dalam https://asean.org/aseansocio-cultural/asean-ministerial-meeting-on-environmentamme/ [Diakses 1 Oktober 2019].

Chen, Lee Chen dan Lau Xin Y, 2015. "Mobilizing Mass Efforts to Fight the Haze in Southeast Asia", Singapore Institute of International Affairs, 27 November [daring]. Tersedia dalam http://www.siiaonline.org/mobilizing-mass-efforts-to-fightthe-haze-in-southeast-asia/_[Diakses 2 Oktober 2019].

CNN,2019“ASEANPunya KesepakatansoalAsap,Apakah Berfungsi?” [daring]. Tersedia dalam https://www.cnnindonesia.com/ internasional/20151009135736-106-83942/asean-punyakesepakatan-soal-asap-apakah-berfungsi [Diakses 4 Oktober 2019].

DW, 2015. "Perusahaan Pembakar Hutan Masih Menunggak Denda" [daring]. Tersedia dalam https://www.dw.com/ id/perusahaan-pembakar-hutan-masih-menunggakdenda/a-47529039 [Diakses 1 Oktober 2019].

DW, 2015. "Diprotes Indonesia, Singapura Tetap Kejar Perusahaan Penyebab Kebakaran Hutan" [daring]. Tersedia dalam https://www.dw.com/id/diprotes-indonesia-singapuratetap-kejar-perusahaan-penyebab-kebakaran-hutan/ a-19376329 [Diakses 1 Oktober 2019]. 
Haze Action Online, t.t. "Standard Operating Procedure for Monitoring, Assessment and Joint Emergency Response", ASEAN Haze Action Online [daring]. Tersedia dalam http://haze.asean.org/standard-operating-procedure-formonitoring-assessment-and-joint-emergency-response/ [Diakses 2 Oktober 2019].

Mongabay, 2015. "1,7 Juta Hektar Lahan Terbakar, Indonesia Mulai Terima Bantuan Negara Lain" [daring]. Tersedia dalam https://www.mongabay.co.id/2015/10/09/17-juta-hektarlahan-terbakar-indonesia-mulai-terima-bantuan-negaralain/ [Diakses 7 Oktober 2019].

Okezone, 2019. "Alasan Indonesia Tidak Terima Tawaran Malaysia-Singapura Padamkan Karhutla" [daring]. Tersedia dalam https://nasional.okezone.com/ $\mathrm{read} / 2019 / 09 / 21 / 337 / 2107628 /$ alasan-indonesia-tidakterima-tawaran-malaysia-singapura-padamkan-karhutla [Diakses 7 Oktober 2019].

TUK Indonesia, 2016. "Seruan Koalisi Masyarakat Sipil Internasional atas Kebakaran Hutan, Lahan, dan Gambut” [daring]. Tersedia dalam https://www.tuk.or.id/2016/04/27/seruan-koalisimasyarakat-sipil-internasional-atas-kebakaran-hutan-lahandan-gambut/ [Diakses 9 Oktober 2019].

World Bank. 2015. "Krisis Kebakaran dan Asap Indonesia" [daring]. Tersedia dalam https://www.worldbank.org/in/news/ feature/2015/12/o1/indonesias-fire-and-haze-crisis [Diakses 1 Oktober 2019]. 